\title{
Power Politics: Advocacy to Activism in Social Justice Counseling
}

\author{
Marian A. Lee, Tammy Jorgensen Smith, and Ryan G. Henry \\ University of South Florida
}

\begin{abstract}
The authors seek to initiate a broader dialog within the social justice movements across disciplines to include a deeper understanding of how power politics plays out in the social/political domain of the public arena outlined in the American Counseling Association (ACA) Advocacy Competencies. In this domain, counselors act as legislative/policy change advocates. However, in recent years social justice advocates within the profession have called for a more activist stance focusing on changing social structures of unjust systems and institutions as an adjunct to legislative/policy advocacy. Activities engaged in by policy/legislative advocates and structural change activists are discussed. Delineation between the differences in perception of power by political operatives and counseling professionals is examined so counselors may have a more comprehensive understanding of the challenges associated with being social change agents. Future implications for the field are discussed with focus on evidence-based research, training, and the potential use of technology and social media in the social justice advocacy movement.
\end{abstract}

Keywords: Social justice counseling, power, advocacy, activism, policy 


\section{Introduction}

The counseling profession has evolved over the last twenty years by the recognition that "the etiology of a client's distress is not simply an intrapsychic phenomenon but oftentimes a sociocultural and environmental one" (Arrendondo, Tovar-Blank \& Parham, 2008, p. 266) and that counselors have "a responsibility to make the environment more conducive to positive human development" (Toporek, Lewis \& Crethar, 2009, p. 260). As a result, acknowledgement of advocacy as central to competent practice culminated in the development and adoption of advocacy competencies by the ACA Governing Council in 2003. The Advocacy Competencies represent a paradigm shift "from the passivity of one-to-one client intervention to large-scale public action in political and policy arenas" (Lee \& Rogers, 2009, p. 287) as a professional and political imperative (Lopez-Baez \& Paylo, 2 009; Ratts, 2009; Speight \& Vera, 2004).

- The goal of the social justice movement within the counseling profession is to "...connect human development issues with toxic environmental conditions" (Ratts, 2009, p 163) and shift the counseling paradigm to address mental health issues from a larger social justice perspective. Therefore, although activity in the public arena where policy and legislation is formulated is not client specific, this systemic level of intervention requires counselors to assume an advocacy role at the macro level on behalf of marginalized or oppressed client groups (Lee \& Rogers, 2009; Toporek et al., 2009). Although social justice advocacy takes place on all political levels of governance - from local town councils to international agencies such as the United Nations and the International Court of Justice in The Hague - the article pays primary attention to the national level of engagement in the United States. At this level, decisions are made affecting lives in the USA across a broad range of issues that supersede lower levels of governance.

Social justice counseling includes case and cause advocacy. Case advocacy takes place when counselors help empower individuals and families to act on their own behalf to fulfill their needs. Cause advocacy requires counselors to stand with or act on behalf of individuals and communities to achieve a more just and equitable position within society (Crethar \& Winterowd, 2012; McNutt, 2011). The ACA Advocacy Competencies divide case and cause advocacy (also called class advocacy) into three intervention levels: client/student (micro level), school/community (meso level) and public arena (macro level) consisting of two domains under each for a total of six domains. The six domains include: client/student empowerment and client/student advocacy under micro level interventions, community collaboration and systems advocacy under meso level interventions, and public information and social/political advocacy under macro level interventions (Toporek, et al., 2009). This article specifically focuses on the social political domain in the public arena where advocates intervene for macro level systemic change.

According to Toporek, Lewis, and Crethar (2009), counselors regularly act as change agents in the systems that affect their own students and clients most directly. This often leads to the recognition that some of the issues and concerns addressed have affected people in a larger arena. When this happens, counselors use their skill to carry out social/political action using the following social/political advocacy counselor competencies: 
- Ability to distinguish issues that can be best resolved through social/political advocacy.

- Ability to identify the appropriate mechanisms and avenues for addressing these issues.

- Ability to seek out and join with potential allies.

- Ability to support existing alliances for change.

- With allies, ability to prepare convincing data and rationales for change.

- With allies, ability to lobby legislators and other policy makers.

- Ability to maintain open dialogue with communities and clients to ensure that the social/political advocacy is consistent with the initial goals.

Understanding the strategic components of power politics is necessary to be effective in all areas of advocacy to achieve goals for tuning, incremental and/or structural change. Challenges encountered by taking on the role of social justice advocate are discussed with regard to necessary political skills, counselor temperament and the work environment in the political arena. Specific goals of the article are:

- To initiate a broader dialog within the social justice movements across disciplines to include a deeper understanding of power politics played out in the social/political domain of the public arena outlined in the ACA Advocacy Competencies.

- To delineate between the differences in how power is perceived and practiced in the political versus the counseling profession so counselors may have a more comprehensive understanding of the challenges associated with being social change agents.

- To present strategies and tactics ranging from policy advocacy activities to activism activities so that counselors can engage to become social justice advocates and/or structural change agents.

- To present future implications for the field in promoting social justice advocacy as a "fifth force" among counseling paradigms.

Table 1 includes a list of terms referenced in the article. Definitions and examples of each are provided for clarity. Strategies and tactics for social/political advocacy engagement are outlined in the narrative of this paper as well as in Table 2. 
Table 1: Term Definitions

\begin{tabular}{|c|c|c|}
\hline Term & Definition & Examples \\
\hline Social Justice & $\begin{array}{l}\text { Fundamental valuing of fairness and } \\
\text { equity in resources, rights and } \\
\text { treatment for individuals and groups } \\
\text { that do not share equal power in } \\
\text { society. (Nilsson, 2011) }\end{array}$ & $\begin{array}{l}\text { Equity (fair distributions of } \\
\text { resources), Access (resources, } \\
\text { information, power for wellness } \\
\text { and self-determination), } \\
\text { Participation (members of society } \\
\text { contribute to decisions that affect } \\
\text { them), Harmony (balance } \\
\text { between individual needs and best } \\
\text { outcomes for society as a whole) } \\
\text { (Crethar et al., 2008). }\end{array}$ \\
\hline Power & $\begin{array}{l}\text { The ability to realize outcomes } \\
\text { based on control of allocative } \\
\text { (material) and authoritative (control } \\
\text { of societal organization) resources. } \\
\text { (Allen, 2003; Stivachtis, 2008) }\end{array}$ & $\begin{array}{l}\text { Allocative- financial, military } \\
\text { weaponry. Authoritative- legal } \\
\text { (judicial systems), political } \\
\text { (legislative, executive bodies) or } \\
\text { moral (religious institutions) } \\
\text { (Stivachtis, 2008). }\end{array}$ \\
\hline Power Politics & $\begin{array}{l}\text { Allocation and distribution of power } \\
\text { through building coalitions and } \\
\text { networks to expand and consolidate } \\
\text { a base from which to exercise } \\
\text { political power. (Silverstein, 2007; } \\
\text { Stivachtis, 2008). }\end{array}$ & $\begin{array}{l}\text { Corporate and non-profit } \\
\text { lobbyists, political parties, grass } \\
\text { roots organizations and citizen } \\
\text { groups, governmental entities, } \\
\text { political operatives in and outside } \\
\text { of Congress (Sharp, 2010, McNutt, } \\
\text { 2012). }\end{array}$ \\
\hline Social Policy Advocacy & $\begin{array}{l}\text { Influencing and/or changing public } \\
\text { policy within a large public arena to } \\
\text { promote fairness and consistency. } \\
\text { (Toporek et al., 2009) }\end{array}$ & $\begin{array}{l}\text { Testifying before legislative } \\
\text { committees. Direct involvement } \\
\text { with policymakers in articulating } \\
\text { and drafting policy purpose and } \\
\text { goals for implementation } \\
\text { (Jansson, 2003). }\end{array}$ \\
\hline $\begin{array}{l}\text { Social/Political } \\
\text { Activism }\end{array}$ & $\begin{array}{l}\text { Direct action to change political and } \\
\text { social structures. (Arrendondo \& } \\
\text { Perez, 2003) }\end{array}$ & $\begin{array}{l}\text { Protests, civil disobedience, social } \\
\text { networking technology for } \\
\text { mobilization, boycotting, petition } \\
\text { drives, walkouts, strikes, sit } \\
\text { downs, picketing (Sharp, 2010). }\end{array}$ \\
\hline
\end{tabular}




\begin{tabular}{|c|c|c|}
\hline Tuning Change & $\begin{array}{l}\text { Change on the part of individuals } \\
\text { and groups, which require adjusting } \\
\text { to existing social structures (Speer, } \\
\text { 2008). }\end{array}$ & $\begin{array}{l}\text { Empowerment through social } \\
\text { support, information, resources, } \\
\text { workplace culture to adjust to the } \\
\text { impact of global forces on the } \\
\text { work environment (Speer, 2008). }\end{array}$ \\
\hline Incremental Change & $\begin{array}{l}\text { Increase of assets (knowledge, } \\
\text { wealth and social resources) in real } \\
\text { terms but the share or proportion } \\
\text { does not change in relation to the } \\
\text { larger system (Speer, 2008). }\end{array}$ & $\begin{array}{l}\text { Increasing the cooperative } \\
\text { atmosphere in school through } \\
\text { more student/ parent input but } \\
\text { overall, the decision-making } \\
\text { power of the teachers and } \\
\text { administration remains } \\
\text { proportionally the same (Speer, } \\
\text { 2008). }\end{array}$ \\
\hline Structural Change & $\begin{array}{l}\text { Individuals or populations alter } \\
\text { relative proportion of assets in } \\
\text { relation to the larger systems } \\
\text { (Speer, 2008). Recognizing and } \\
\text { changing cultural or institutional } \\
\text { barriers that impede well-being } \\
\text { (Ratts, 2009). Using power to } \\
\text { change institutional structures } \\
\text { (government, political and private) } \\
\text { to ensure policies, laws and } \\
\text { practices are more just and } \\
\text { equitable in order to fulfill individual } \\
\text { and collective needs (Speight \& } \\
\text { Vera, 2004; Prilleltensky, 2008). }\end{array}$ & $\begin{array}{l}\text { Mobilizing citizens to define } \\
\text { debate on community } \\
\text { infrastructure maintenance and } \\
\text { shift a greater proportion of the } \\
\text { local government budget in } \\
\text { relation to the overall budget to } \\
\text { address this concern (Speer, } \\
\text { 2008). Reform healthcare system } \\
\text { infrastructure from one that } \\
\text { medicalizes mental and public } \\
\text { health issues to one that } \\
\text { recognizes the connection } \\
\text { between justice and wellness and } \\
\text { responds accordingly with } \\
\text { changes in policy and procedures } \\
\text { for treatment (Durenberger \& } \\
\text { Foote, 1993). Civil Rights } \\
\text { Movement which replaced state } \\
\text { segregation laws with national civil } \\
\text { rights legislation (Graham, 1990). }\end{array}$ \\
\hline
\end{tabular}


Table 2: Policy Advocacy and Structural Change Activism Activities

\begin{tabular}{|c|c|}
\hline Activity & Description \\
\hline $\begin{array}{l}\text { Expert Testimony/Policy } \\
\text { Research (policy advocacy) }\end{array}$ & $\begin{array}{l}\text { - Expanding rights and benefits by testifying in support or } \\
\text { opposition to legislation or policy initiatives, providing } \\
\text { direction on how public officials might achieve goals with } \\
\text { regard to policy/legislative initiatives, challenge } \\
\text { misperceptions of public policy issue (Task Force, 1986) } \\
\text { - Protect existing funding streams (McNutt, 2012) } \\
\text { - } \text { Framing issues in terms of effect on constituents, } \\
\text { composing concise written statements for distribution to } \\
\text { legislators and media, presenting policy research findings } \\
\text { (Lee, et al., 1994) } \\
\text { Challenge prevailing assumptions, raise new issues } \\
\text { (Phillips, 2000) }\end{array}$ \\
\hline $\begin{array}{l}\text { Policy Formation and } \\
\text { Evaluation (policy advocacy) }\end{array}$ & $\begin{array}{l}\text { - Identify and define problem; Analyze current policy, bring } \\
\text { stakeholders together to decide on optimal plan of action, } \\
\text { develop a plan and prescription for acting on problem, } \\
\text { organize expert testimony and interest group support, } \\
\text { gain sanction from relevant officials and legislators for } \\
\text { plan of action, Implement policy to targeted constituency } \\
\text { and evaluate impact of policy, suggest changes to } \\
\text { increase effectiveness (Task Force, 1986) } \\
\text { - Condense, interpret and disseminate policy/legislative } \\
\text { initiatives in meaningful form (Wolff, 2000) } \\
\text { Acquire and process data to validate policy/legislative } \\
\text { goals, develop and promote legislative proposals (DeLeon, } \\
\text { et al., 1984) } \\
\text { Manage bills through the legislative process, establish } \\
\text { relationships with committees and subcommittees } \\
\text { responsible for policy issues, organize conferences on } \\
\text { policy/legislative initiatives, Research federal laws } \\
\text { impacting policy/legislative initiatives (Lee, et al., 1994) }\end{array}$ \\
\hline
\end{tabular}




\begin{tabular}{|c|c|}
\hline $\begin{array}{l}\text { Lobbying for Policy Change } \\
\text { or Support (policy advocacy) }\end{array}$ & $\begin{array}{l}\text { - Organize meetings with legislators and policy makers, } \\
\text { frame issues on how affect office holder constituents, } \\
\text { disseminate relevant information to media outlets, target } \\
\text { committee and subcommittee members overseeing } \\
\text { legislation pertinent to policy/legislative agenda, } \\
\text { collaborate with other interest groups to increase } \\
\text { resources, cohesion and numbers for greater influence, } \\
\text { keep abreast of current legislation, congressional } \\
\text { hearings, media reports, political climate, and other } \\
\text { experts, advocates and special interest group lobbying } \\
\text { activities (Lee, et al., 1984) } \\
\text { Coordinate grass roots or constituent support for position } \\
\text { to achieve an elected officials shift in stance on issue, act } \\
\text { as expert witnesses, attend conferences (Task Force, } \\
\text { 1986) } \\
\text { Socialize and develop relationships with political } \\
\text { operatives, legislative staff and elected officials, provide } \\
\text { timely information to become credible resource to those in } \\
\text { positions of power to effect change (Vincent, 1990) } \\
\text { Gain knowledge of substance of policy and legislative } \\
\text { procedures, reduce complex data into simple, yet } \\
\text { informative memos and talking points within political } \\
\text { context (DeLeon, et al., 1984) }\end{array}$ \\
\hline $\begin{array}{l}\text { Organizing to change status } \\
\text { quo (structural change } \\
\text { activism) }\end{array}$ & $\begin{array}{l}\text { Petition drives, picketing, performance art, teach-ins, } \\
\text { vigils, overloading administrative systems, rent } \\
\text { withholding, strikes, walk-outs, protests, marches, } \\
\text { blacklisting, slow downs, sit downs, dumping, } \\
\text { demonstrations (Sharp, 2010) } \\
\text { Mobilizing volunteers, boycotting, fasting, being arrested, } \\
\text { nonviolent civil disobedience, community building } \\
\text { (Arredondo \& Perez, 2003). }\end{array}$ \\
\hline
\end{tabular}

\section{Impact of Social/Political Injustice}

In recent years, the focus within the profession has been on the public arena of advocacy specifically at the macro level of intervention in the social/political domain where legislation and public policy are made and structural change occurs. Counselors have been called on to become systemic change agents who "challenge social, cultural, or economic barriers to optimal psychosocial development" (Lee \& Rogers, 2009, p. 284). At this level of engagement, counseling clearly becomes a political endeavor since interventions seek to change governmental and political systems so they are more just and equitable towards marginalized individuals and communities (Lopez-Baez \& Paylo, 2009). The focus on the public arena is 
particularly salient in light of research showing the continued impact of power, privilege and oppression on marginalized members of society and the growing awareness of the connection between oppression and poor outcomes in mental health (Aldarondo, 2007; Jacobs, 1994; Prilleltensky, 2008). This connection is further supported by recent research on the correlation between inequity and individual and collective well-being found in countries with higher income inequality such as the United States, United Kingdom and Portugal versus countries with low income inequality such as Japan and Sweden. Results indicated that countries with higher income inequality shared a myriad of pressing problems such as: greater levels of mental illness, consumption of more drugs, lower levels of general health, lower life expectancy, lower education performance, more teenage pregnancies, more violence and crime, poorer career prospects for disadvantaged children, higher rates of prison overcrowding and higher rates of obesity (Wilkinson \& Pickett, 2009).

Social theorist Michel Foucault claimed that power could never be separated from the effects of power (Angelique, 2008). This is clearly indicated through a deeper understanding of the political and psychological dynamics of oppression where the power of oppressor goes hand in hand with the suffering of the oppressed. Oppression is both external and internal. External political forces (legal, military, economic and social barriers) can deprive individuals and groups the benefits of personal (self-determination), relational (democratic participation) and collective (distributive justice) wellness. When these restrictions are internalized, they serve as a personal censor operating on the psychological level to negate personal power by instilling a belief of not deserving of the same share of resources and participation in society as more powerfully entrenched and privileged groups (Prilleltensky, 2008).

Although much evidence exists on the powerful impact of socioeconomic, cultural, and contextual factors shaping the lives of individuals, families and communities, counselors have continued to focus on person-centered approaches to empower clients and promote wellness (Aldarondo, 2007; Prilleltensky, 2008). However, wellness is based not only on personal and relational needs (intrapsychic orientation) but also on collective needs (interpsychic orientation) and is bound up with institutional structures that affect everyday life. Therefore, the focus only on individual wellness may be misplaced as "...a culture that emphasizes individualism and blames victims for their misfortune is bound to fix people and not structures." (Prilleltensky, 2008 , p. 126). Counselors as social justice advocates can serve their clients more effectively by understanding the dynamics between psychological and political oppression (Prilleltensky, 2008). Psychological mechanisms (behavioral, cultural, linguistic, material and cognitive) of oppression can mask or completely obscure its political roots. Moreover, the more oppression is internalized by clients through psychological mechanisms, the less they will connect their suffering to unjust political conditions" (Prilleltensky, 2008).

Since justice and wellness are inexorably linked and while both are deemed central to a good society, neither is evenly distributed (Prilleltensky, 2008). Therefore, this link between justice and wellness is receiving greater attention by counseling professionals across disciplines from social workers, community psychologists, counseling psychologists and school counselors to marriage and family and individual counselors. (Almeida, Dolan-Del Vecchio \& Parker, (2008); Lee \& Rogers, 2009; Prilleltensky \& Fox, 2007; Ratts, 2009; Rountree \& Pomreroy, 2010). Since wellness depends on the just allocation of resources and opportunities at the individual and collective levels, interventions in the sociopolitical domain where power and political interests determine who controls these resources will be required (Prilleltensky, 2008; 
Stivachtis, 2008). This understanding of the connection between wellness and justice has galvanized many in the counseling profession to call for social justice advocacy to become the "fifth force" among counseling paradigms to complement the previous counseling forces of psychodynamic, cognitive behavioral, existential-humanistic and multicultural (Ratts, 2009). Social justice advocates within the profession believe counselors must be willing to assume the advocacy role by becoming an active voice and conduit for change in the social/political domain of the public arena. Counselors do this within the framework of "... one's professional advocacy competencies to act on behalf of client groups who are marginalized or oppressed at the macro level" (Lee \& Rogers, 2009, p. 284). Advocating within the social/political domain includes but is not limited to working with: "non-profit organizations, Federal, state and local political institutions, government agencies, non-governmental organizations (NGOs), small private sector business firms, and multinational organizations and corporations" (Partridge, 2008, p. 169).

\section{Lack of Preparation to Engage in the Social/Political Domain}

Even though the need for social justice advocacy in the social/political domain is warranted, counselors are not always prepared or politically adept to enter into this arena where power politics is played (Smith, Reynolds \& Rovnak, 2009). Moreover, since distributive justice is the focus and goal of many advocacy interventions, any intervention process that deals with resource allocation is political. As a result, a counselor advocate is likely to come up against entrenched systems maintained by professional political operatives who not only are comfortable engaging in political battles but have a wealth of experience and resources at their command to prevail (McNutt, 2012). A paradigm shift to a more activist role in creating "...sociopolitical change to dismantle the current status quo" (Chang, Crethar \& Ratts, 2010, p. $27)$ requires that counselors understand and contend with the political dynamics of change and wielding the instruments of power effectively.

Many social justice advocacy activities require a unique skill set which includes a primary emphasis on verbal and written communication along with legislative procedural skills, proficiency locating funding sources, strategic use of mass media (including the internet and social media sites), ability to translate abstract principles into concrete policies, information management skills (processing and dissemination), initiate litigation, and the ability to develop and implement political strategies. Additional skills include orchestrating pressure on decision makers, conveying strategic vision to all stakeholders, and seeking positions of power (DeLeon, Frohboese \& Meyers, 1984; Jansson, 2003; Lee \& Rogers, 2009; Sharp, 2010; Wolff, 2000). Advocating effectively requires considerable knowledge of lobbying rules and regulations, legislative processes, community organizing, public education programs, political action committees (PACs), political campaigning, policy research, government structures, key committees in state and federal jurisdictions, and political economies of social agencies, programs and communities. In addition, an understanding of the mindset of elected politicians and non-elected civil servants, political appointees, interest group coalitions and voter constituency groups is needed. Finally, experience in the practice of practical politics is a key component of effective advocacy requiring specialized training and/or mentoring (Jansson, 2003; McNutt, 2012).

In light of this necessary skill set and knowledge base required for effective social justice advocacy, simply possessing the mission and desire to influence public policy and create social 
change is not the same as actualizing social change in the public arena (McNutt, 2012). Engagement in the public arena may be more involved and complicated than most counselors anticipate, so the evolution of the profession towards a social justice advocacy paradigm speaks to the need to explore and consider the political realities of legislative/policy and structural change. As counselors move from the micro and meso levels into the macro level of intervention in the social/political domain outlined in the ACA Advocacy Competencies, the authors argue for a more realistic assessment of social justice advocacy by looking with an appreciative eye on the activities and challenges of engagement in the larger public arena.

Systemic Change in the Public Arena

From a broad ecological perspective, policy advocacy and political activism are often lumped together when describing social justice advocacy interventions. While acknowledging the multiple layers of influence on individual lives from the immediate (individual, family and community) context to the larger social/political context (Phillips, 2000), the counseling profession has not specifically delineated the differences in how change is achieved within the social/political domain of the public arena (Toporek et al., 2009). While the ACA Advocacy Competencies do provide a framework for interventions at the macro level, for the most part they focus on influencing public policy at the macro level with no direct reference to political activism required for structural change

At times policy advocacy and political activism may overlap, however distinct differences exist based on the level of confrontation, strategic orientation and types of systemic engagement. In general, policy advocacy engages the status quo through negotiation and collaboration to obtain resources and effect policy change for a particular underserved constituency (Jansson, 2003; Speer, 2008), while activists seek to change or dismantle the status quo itself (Chang et al., 2010). Mediating, negotiating or lobbying state and Federal agencies for increased mental health care funding for underserved communities is an example of advocating for policy change. Structural change activists would focus on actively confronting and working toward dismantling and then replacing the current health care system itself in order to provide more equitable mental health services to marginalized communities. Both policy and structural change require that social justice advocates understand political systems and the effective use of the instruments of political power (Speer, 2008).

\section{Policy/Legislative Advocacy: Tuning and Incremental Change}

Policy making is "part information, part ideology, and part drama" (Phillips, 2000 p. 401) in which multiple factors such as: values, election cycles, prior decisions, interest group pressure, public and constituent support or opposition, relevant research, cost-effectiveness, immediate events, funding, and legal ramifications exert influence (Phillips, 2000; Lee, et al., 1984; McNutt, 2012). Three prominent areas of policy advocacy are: expert testimony/policy research, policy formation and evaluation, and lobbying for policy change or support. Counselors may function in any or all of these roles in the practice of social justice advocacy either as an external (constituent, expert witness, consultant or lobbyist) or internal (legislator or professional staff/political operative) player in the political process (Lee, et al., 1984; DeLeon, et al., 1984; Task Force, 1986). 
Counselors engaging in policy advocacy have many transferable skills and strengths to bring to the policy/ legislative process, chief among them an understanding of process and how change occurs in therapy as well as creating processes "where everyone has a voice and where powerful individuals do not dominate the dialogue" (Doherty, Mendenhall \& Berge, 2010, p. 393). Other transferable skills include: patience, experience working collaboratively with diverse clientele, caring, goal setting, asking key questions that move the process forward, working well with others by forging a common purpose across differing needs and agendas, non-verbal and verbal communication skills, a multi-systems perspective, appreciation for human suffering, translating abstract theory into concrete practice, organization and planning to accomplish goals, knowledge of group dynamics, consensus building and conflict resolution skills (DeLeon, et al., 1984; Doherty, et al., 2010; Kiselica \& Robinson, 2001; Smith et al., 2009). All of these skills can be brought to bear on the public policy/legislative process which, at its core, involves compromises and trade-offs among alternative choices championed by competing interests (DeLeon et al., 1984; Vincent, 1990).

Be that as it may, oftentimes counselors' expectations are not realistic especially when interacting with government institutions and political systems such as legislatures, which, in many instances move slowly to address policy and legislative issues (Jansson, 2003). While some intervention outcomes are easily measured goals such as passing laws and preserving funding, other outcomes defy clear and easy evaluation such as gaining political influence and access through constituent empowerment, providing a more just distribution of resources or creating a sense of hope (McNutt, 2012). Several challenges counselors may face when intervening as a policy advocate include:

\section{Elites advocating elites}

Policy advocacy emphasizes mobilizing elite institutions (outside of the control of the population for which services are provided) such as agencies, non-profits, courts, charity foundations and the media by relying on appeals to fund programs and/or achieve policy changes on behalf of others (Jenkins, 2002). This means in effect that "...counselors often have to reach out to groups who have the power to effect positive changes in a client's life" (Kiselica \& Robinson, 2001, p. 79) through collaboration and cooperation. Change, therefore, may be limited to those options that are within the capacity of, or are palatable to, elite decision-makers (Jenkins, 2002). In addition, some practitioners in the profession also have warned against "elites advocating elites on behalf of non-elites" (Doherty, 2008, p. 2) and whether it is appropriate for professionals to be in any type of social change leadership role especially with regard to differences in race and culture (Jenkins, 2002). In answer to the last warning, Doherty (2010) proposed counselor advocacy based on a Public Work Model that emphasized counselors working as "citizen professionals" alongside individuals and families impacted by the larger political and governmental systems in which they must function. Acting as citizen professionals to address systems disparity moves counselors away from advocacy approaches to social change "in which the expert professional attempts to obtain resources on behalf of passive communities" (Doherty, 2010, p. 390) to the role of collaborative partners and/or catalytic leaders. 


\section{Secrecy and hidden agendas}

The dynamics of the decision making process that accounts for policy formation is often cloaked in secrecy or obscured by a labyrinth of legislative procedures which may be influenced more by party loyalties, friendships and campaign funding with minimal connection to the policy issues at hand (Vincent, 1990; McNutt, 2012). Moreover, most counselors intervene in policy initiatives in response to outcomes. However, to effectively influence those policy outcomes, intervention must occur on the front end when policy is formulated and political maneuvering is most obscure (McNutt, 2012; Partridge, 2008). In working towards legislative and policy changes, advocates may run the risk of being used by legislators who desire to give the appearance of concern and assistance but answer to other more powerful interests (Silverstein, 2007). Testifying before a committee or visiting congressional representatives and senators may perform an educative function but does not necessarily change policy much less inequitable discriminatory social and political structures. Counselors working in legislative settings may become frustrated and disillusioned by the perception that their contributions "...are substantially diminished, if not completely thwarted, by the very nature of the legislative process (DeLeon et al., 1984). In addition, policy makers often view advocacy efforts as predictable partisan promotion with the hidden political agenda of benefitting the particular profession rather than those served (Doherty \& Carroll, 2002). This attitude may discourage well-intentioned and necessary advocacy efforts.

\section{Deception and misinformation.}

Political operatives often intentionally distort an issue and use deception to maintain system norms to achieve their ends (McNutt, 2102). Since resource allocation invariably has political overtones, authority figures in the political arena frequently transmit values that reinforce inequity and create a false consciousness among the electorate (Prilleltensky \& Fox, 2007). Through the instillation of false consciousness - "the holding of false or inaccurate beliefs that are contrary to one's own social interest" (Jost \& Choen in Prilleltensky \& Fox, 2007, p. 798) people inadvertently contribute to the further maintenance of their disadvantaged position, which sustains the domination of political and social elites (Prilleltensky \& Fox, 2007). Due to other variables that influence the policy process such as, news events, competing legislation, political scandals, public perception and constituent support or opposition, revealing the actual details of the decision making process in a politically charged climate sometimes does not make for good political strategy. Secrecy and possible deception used to achieve political ends results in the admission of untrustworthy artifacts (documents and subsequent reflective writings) into research designed to examine effective social justice interventions. In addition, verbal statements of the parties involved in policy decision-making may be questionable (McNutt, 2012).

\section{Political nature of policy making}

Legislative work is neither methodical nor neutral. On the one hand there is often little time for reflection on some legislative issues, while work on other legislative issues, such as healthcare, may drag on for years. Legislators are affiliated with political parties, particular political agendas, beholden to voters in their districts, answerable to campaign contributors, and influenced by lobbyists. In the legislative/policy arena, especially at the national level within the context and culture of Capitol Hill, a powerful dynamic of interdependence exists and "one 
cannot do one's own work separate from the needs, problems, and agendas of other people" (Vincent, 1990). This dynamic results in a political process whereby issues are resolved "...that may have more to do with political expediency and/or personalities than with the objective merits of any issue" (DeLeon et al., 1984). Therefore, "policymaking is ideologically and politically driven" (Partridge, 2008, p. 169) and rarely reflects empirical outcome considerations by actions taken in communities (Birnbaum, 2000; Partridge, 2008). Interpreting information is often done within a political rather than an evidenced-based context, so counselors should be prepared to make recommendations from gathered data that are not only substantively but also politically sound (DeLeon, et al., 1984). Policy proposals that offset spending increases with budget cuts that claim cost-effectiveness, as well as, those that affect constituents take precedence in the legislative process. Value choices also affect policy making and, therefore, few issues find their way onto the public or legislative agenda that have clear-cut outcomes (Phillips, 2000). Finally, according to McCarty (2007), over the past 30 years, polarization of ideologies at the congressional and state legislative level has resulted in a restrictive political culture where problem solving has taken a back seat to narrow group interests and cynical political calculations. This dynamic has diminished the capacity of legislative bodies to engage in policymaking through compromise and consensus building.

\section{Shifting nature of policy advocacy campaigns}

Advocacy campaigns tend to shift often in response to political expediency or necessity, which makes effective interventions and goal setting frustrating if not nearly impossible. Coalition partners may change, funding waxes and wanes, legal issues may arise, bills may be intentionally defeated due to harmful amendments or held up for ideological reasons, or strategic lawsuits may be filed to soften a target to achieve better outcomes, all of which rarely result in a predictable chain of discrete decisions and events leading to a targeted policy outcome (McNutt, 2012; Phillips, 2000). Finally, decisions are often made on a split-second basis-a bill on the table one minute, off the next-providing little time for reflection and research on fundamental issues (DeLeon et al., 1984).

\section{Legislative staff interactions}

The majority of legislative staff members are caseworkers responsible for individual constituent problems rather than policy/legislative issues that tend to be addressed in the committees and subcommittees. Therefore, knowledge of the political process and key players on these committees is essential for effective policy advocacy. Due to the sheer demand on an elected official's time, select staffers who are policymakers in an area of expertise filter information to their respective bosses, becoming in effect a functional gatekeeper (Lee et al., 1994). In addition, the turnover of legislative staff, as well as elected officials can be high so reestablishing rapport and educating new members on the merits of a proposed policy initiative can be time consuming and frustrating (DeLeon et al., 1984).

\section{Social/political advocacy}

Within the ACA Advocacy Competencies focuses the counselor advocate's attention on problems that can be addressed at the policy/legislative level in the public arena (Toporek et al., 2009). More often than not, this type of intervention involves tuning or incremental change. While short-term victories may be won by relying on elite sources of power (Jenkins, 2002), 
counselors practicing this type of advocacy are rarely successful at bringing about structural changes they seek in the public arena (Speer, 2008). Since politicians prefer feasible costeffective short-term responses linked to immediate and pressing problems, "investments in genuinely restructuring or redistributive policies are highly unusual" (Phillips, 2000). Structural change is the only means to increase the proportion of resources in relation to the whole population and, therefore, tuning and incremental changes "fall short of having substantial or meaningful benefit for the targets of empowerment efforts" (Speer, 2008, p. 206).

\section{Political Activism: Structural Change}

American theologian Reinhold Niebuhr viewed conflict as necessary to address inequities stemming from unequal distribution of power. In his view, due to the amoral nature of power, power can only be challenged by power (Niebuhr, 1932). Saul Alinsky, a mid twentieth century labor organizer educated as a sociologist and historically one of America's best known community activists, echoed this understanding of power believing the only effective means to challenge existing power structures is "... with countervailing power-not by an appeal to reason or justice" (Speer, 2008, p 204). "Change means movement. Movement means friction" (Alinsky, 1971, p. 22) and, therefore, conflict is inevitable when changing the status quo. The primary example in recent American history of structural change comes from the civil rights movement, which mobilized activists to overturn the legal structure of segregation. The dismantled structure of segregation was then replaced by the enactment of civil rights legislation (Graham, 1990).

Policy and legislative advocacy requires cooperation but for structural change to occur, "the issue of cooperation is complicated by the fact that any efforts that successfully challenge oppression and injustice in the status quo will meet with strong resistance" (Speer, 2008, p. 204). Structural change is further compounded by the fact that many national advocacy organizations, formed since the 1960s to represent and advocate for policy and structural changes on behalf of disadvantaged groups, now tend to be composed of highly educated donors. No longer is the base of support politically active and mobilized members from the affected groups themselves. Activist membership organizations, such as labor or civil rights groups, which are able to take direct political action by mobilizing their rank and file into largescale movements with widespread participation, can exert greater organizing power and political muscle to hold politicians accountable. Instead, the trend towards donor supported advocacy organizations makes disadvantaged groups easier to ignore in the political process (Skocpol, 2007).

Political theorist, Robert Dahl expressed concern that the decline of direct citizen influence over elected representatives and government decisions would give rise to new levels of political inequality heretofore unknown (Ringen, 2008). In addition, a strong concentration of abundant wealth found in the top one percent "...is creating a new aristocracy of economic power" (Ringen, 2008, p. 285). This power imbalance is now a fact of political life that must be recognized by anyone who needs public money. Furthermore, in the current "show me the money" political environment, elected officials answer more to special well-funded interests rather than voters. Therefore, public policy tends to distort in favor of powerful invested minority interests, which seek to maintain the status quo (Ringen, 2008). For example, research linking lower social economic status with higher incidences of stress and mental illness 
(Aldarondo, 2007; Prilleltensky, 2008) would argue for more funding of mental health services for affected client populations. However, this research is disregarded in the rush to address politically driven state and national budget cuts while other programs lobbied for by corporations and other well-funded interest groups remain intact.

The need to reform the healthcare system infrastructure due to the ever-increasing trend to medicalize mental health and public health issues is garnering more attention from mental health providers. The failure to recognize the connection between justice and wellness often only becomes apparent when it manifests as mental health problems within our communities (Durenberger \& Foote, 1993). This trend ignores the locus of many mental and public health issues and deals with fundamental societal problems (violence, poverty, family disintegration, substance and other forms of abuse) by treating them within the medical insurance model. Medicalizing mental and public health issues "does a disservice to people's needs and creates costly, inefficient, and delayed treatment of society's problems" (Durenberger \& Foote, 1993, p. 281). Structural change would clearly be required to implement policies and healthcare programs more responsive to community needs instead of the corporate interests of pharmaceutical and insurance companies.

Since the role of conflict is inherent in political activism (Alinsky, 1971), tuning interventions and incremental victories become problematic at the macro level of political engagement because all political players are not operating with the same understanding of power and success. Conflict and resistance are inevitable because structural change alters the proportion of resources disenfranchised individuals and groups have vis-à-vis larger systems (Speer, 2008). Understanding power alignments and the strategic use of political, economic and social levers either to block or achieve change is crucial to effect sociopolitical change (Alinsky, 1971, Sharp, 2010). Therefore, as social justice advocates work towards a fifth force in the counseling profession, they need "...to understand and develop interventions that exercise power" (Speer, 2008 , p. 209) to realize the social change outcomes they desire and maintain a strong presence in an arena dominated by vested and/or moneyed interests (Alinsky, 1971; Sharp, 2010; Speer, 2008).

Strategic lawsuits against political participation (SLAPPS) are an example of vested interests' exercise of power to muzzle individuals and community organizations from participating in political forums and expressing views that run contrary to corporate and other vested interest agendas (Speer, 2008). SLAPPS sue community groups for alleged illegal acts such as defamation, conspiracy, personal injury, business damage or nuisance. By using bogus lawsuits, corporations are able to divert attention and resources from the merits of the original issues of concern (harming actions perpetrated on the community by corporate interests) to the alleged wrongdoing by community groups. Community groups are then forced to use their time and scarce monetary resources defending themselves (Speer, 2008). The alternative reframes by corporations masks unjust corporate policies and actions by diverting attention away from the actual concerns of clients and their respective communities (Speer, 2008). Although approximately two thirds of SLAPPS are dismissed for failure by corporations to state a justifiable claim, the average cost of a damage claim is $\$ 9$ million and the average length of time spent in court procedures and legal maneuvering before dismissal is 36 months. Understanding that who defines the parameters of the debate often controls the outcome will enable counselors to be proactive and politically savvy in taking steps to head off possible 
participation obstacles such as agenda setting and alternative reframing of the initial community concerns (Speer, 2008).

Political activism, as opposed to policy advocacy, denotes a more activist oriented stance and moves the counselor into the larger political realm aimed at "the redistribution of power and authority among identity groups within and across societal strata" (Helms, 2003, p. 309). Counselors' work for structural change is, therefore, more influenced by identity politics, culture wars and polarized ideologies (Skocpol, 2007). Counselors as structural change agents will not only encounter strong resistance by "systems that may not be receptive to interventions that threaten the status quo of the high-stakes holders" (Helms, 2003, p. 310) but also pushback due to the use of more confrontational tactics and strategies with the strong potential to antagonize those holding opposing positions. Policy advocacy skills such as collaboration and transparency, while useful in shaping policy outcomes, may not necessarily transfer well into the political arena where confrontation will inevitably occur for structural change to take place. The primary challenge confronting counselors advocating for structural change is engaging entrenched power structures with high levels of built-in resistance consuming an activist's energy and time with little monetary compensation (Smith et al., 2009). Other challenges include: being labeled a trouble-maker or outsider, backlash from entrenched highly resistant systems, taxing work, threats to personal safety, sacrificing a personal life, boundary crossing, dual relationships, jeopardizing professional standing, blind idealism, inadequate legal resources and unrealistic goals (Kiselica \& Robinson, 2001; Smith et al., 2009). Therefore, being an agent of structural change is a calling, not a job, as working for social/political change "may blur the boundary between personal life and professional role" (Lee \& Rogers, 2009, p. 286).

\section{Power Concepts: Counselors vs. Political Operatives}

\section{Counselors}

"Power with" versus "power over" is the mantra of social justice counselors and is about transparent communication and collaboration in pursuit of fairness, access and equity (Angelique, 2008). Power is used for the empowerment of others rather than for dominance by a privileged group. Collaboration is a key component for providing expanded resources and opportunities to help communities become more self-sustaining by building social capital in communities through bridging and bonding. An example of building social capital is working together on policy initiatives with various social agencies and political institutions to effect change (Goodman, Liang, Helms, Latta, Sparks \& Weintraub, 2004). In this context power is associative, an enabling and facilitative medium to achieve common aims (Stivachtis, 2008). As such, the concept of power used by counseling professionals is generally understood as awareness and critical consciousness of power differentials. Counselors then use that awareness to ethically promote equality by empowering communities to seek redress for inequitable distribution of resources.

In the counseling profession power speaks to influence; in politics power speaks to control. Typically, counselors have held an overly individualistic focus. However, according to Riger (1993, p282), "to reduce power to individual psychology ignores the political and historical context in which people operate". A sense of empowerment at the macro level is not the same as the ability to control resources. Without this ability, empowerment becomes depoliticized 
and ineffective (Speer, 2008). While empowerment helps the disempowered gain a voice, "one can become psychologically empowered without having the ultimate authority or power to realize one's objectives" (Zimmerman, 1995, p. 592). Therefore, achieving a sense of empowerment by giving a voice to oppression does not ensure marginalized groups will be successful in promoting and achieving social change or specific desired outcomes.

Counselors who have heretofore operated based on the empowerment process by emphasizing outcomes and impacts may be at a disadvantage when confronting structural systems of injustice (Speer, 2008). For this very reason, collaborative and cooperative policy advocacy may frustrate counselors when operating in the political environment to effect structural change. In addition, counselor advocates acting as social change agents may inadvertently contribute to "transforming the appearance but not the substance of what are, in effect, traditional advocacy campaigns" (Jenkins, 2002, p. 58)

Using critical consciousness in the public arena to build social capital is desirable and sometimes effective, but fails to take into account the potential to "restrict opportunities for challenging power structures and for engaging in constructive conflict" (Prilleltensky, 2008, p. 120). Although some elected officials and political operatives are also concerned with building coalitions and networks to empower disenfranchised groups, counselors should not be naïve about political realities and the fact that those with power "seek to satisfy their needs through their role as gatekeepers for society's resources" (Lorion \& McMillan, 2008, p. 257). Efforts by local communities and/or client populations can be easily thwarted when confronting major corporate or institutional interests if advocates are not cognizant of the power dynamics of engaging entrenched systems.

In the public social/political arena, participatory efforts by citizen groups for social justice may be reduced to nothing more than lip service providing legislators and policy makers with the moral gloss of democratic decision-making (Culley \& Angelique, 2011). Collaboration with policymakers may also depoliticize issues of mental health wellness stemming from oppression because individuals seeking greater social capital are "encountering external forces [of oppression] that, to some extent, they have already internalized" (Prilleltensky, 2008, p. 120). Counselors' traditional focus on empowerment might prove ineffective by attempting to transplant an individualist approach at the micro level to the macro level through the misunderstanding of the relationship between empowerment and power (Speer, 2008).

\section{Political Operatives}

The French philosopher, Blaise Pascal, observed that "Justice without power is impotent; power without justice is tyranny" (Alinsky, 1971, p. 52) implying that both a sense of justice and an understanding of power are necessary to effect change for a more just world. Community psychologist Isaac Prilleltensky (2008) defines power as the ability and opportunity afforded by social and historical circumstances to influence the course of events to either fulfill or obstruct personal, relational and collective needs. He further warns those who make their living in the counseling profession, particularly in community settings, that power is "multifarious and omnipresent [and] ...we need to be cognizant of our own potential collusion with regnant forms of economic, cultural, and political power" (Prilleltensky, 2008, p. 119).

However, in the social/political domain, power is pervasive and often invisible operating in covert ways sometimes hidden behind rhetoric designed to mask motive or ideology (Lens, 
2005). At times, political operatives use power to manipulate, distract, confuse and deceive outright in order to gain complicity or leverage over others (Stivachtis, 2008). For political operatives power is about prevailing by using the instruments of power to control the course of events, not merely influence them. Prevailing requires the ability to realize outcomes based on the control of allocative (material) and authoritative (ability to control societal organization) resources (Allen, 2003; Stivachtis, 2008). The inherent danger for counselors entering the social/political domain in taking on the mantle of social change agent lies in becoming rigid, inflexible and more authoritarian in the pursuit of social justice. If not cognizant of their own power striving behavior, counselors may be liable for actions such as, increasing their own position and power, pursuing personal agendas, becoming the oppressor through the acquisition of additional privileges granted to political leaders, and acting above reproach (Prilleltensky, 2008; Smith, et al., 2009).

Most counselors wish to achieve successful outcomes on behalf of their clients. However in the political arena, high achievement motivation has been found to correlate with an authoritarian style that causes achievement orientated individuals to react to a perceived lack of control with frustration and inflexibility (Winter, 2010). If counselors enter the public arena motivated only by achievement of certain goals and outcomes, they may become discouraged and unable to follow through on commitments. Furthermore, if achievement oriented individuals' sense of control is threatened, they may resort to authoritarian tactics such a micromanagement, rigid persistence in a failing cause, a "my way or the highway" mentality or illegal acts (Winter, 2010). Power orientated people are able to enjoy aspects of the political process disdained by achievement orientated people such as, "negotiation, compromise and bargaining, building alliances and aggregating interests, judicious use of prestige, sanctions, threats, and even aggression" (Winter, 2010, p. 1660). Finally, research further suggests that in "certain kinds of sociopolitical structures with certain types of leaders, we should be concerned about the lack of sufficient power striving" (Winter, 2010, p. 1662).

Social justice advocates, particularly those engaging in structural change, should be conversant with political power and its use without the usual attendant fear of corruption. Power is viewed as corrupted because it is often exercised through reward and punishment, agenda setting, reframing issues to favor specific outcomes, and the use of myth, ideology and control of information to shape citizen consciousness on policies and legislation (Speer, 2008). However, in many cases these are the instruments of power necessary to confront entrenched systems of injustice to bring about structural change. The social/political domain is ever changing depending on public sentiment, the political election cycle, state of the economy, the shifting political ground, political loyalties and alliances, changing strategies and tactics, and the current political and economic forces controlling the government, (Jenkins, 2002; McNutt, 2012), all affecting policy initiatives and political outcomes. Therefore, acquiring personal and collective power and understanding its use to implement political strategy for policy as well as structural change is a necessary requirement to bring about a more just society.

\section{Discussion}

The correlation between justice and wellness has been well documented with regard to inequitable distribution of society's resources. As a result, many counseling professionals are moving out into the public arena-from amelioration of client problems to the transformation of 
the systemic environment in which they live- by employing a more activist and politically informed mode of intervention (Fox, 2008). Social justice advocacy is rarely straightforward as professionals engage in often intense, complex and difficult dilemmas due to the inherent nature of helping disenfranchised clients and communities who often need sustained interdisciplinary interventions (Kiselica, 2004).

While many in the counseling profession possess a level of expertise and comfort advocating for policy and legislative change in the social/political domain, stepping into the fray of confrontational political engagement to institute structural change is another matter. Working as a structural change agent is when the lack of political strategic skills and the personal attributes of a political activist become apparent and many counselors calculate the personal and professional price of activism as too high to pay (Smith et al., 2009). This is arguably where most resistance lies in promoting the evolution of the counseling profession towards a fifth social justice paradigm. As the prospect of engaging in the public arena proves complex and challenging to one's professional interests, time, financial resources and skills, many counselors may tend to default to lower levels of intervention moving from the macro level back to the meso and micro levels of engagement (Fryer, 2008; Ratts, 2011).

Alinsky concluded that "Great dangers always accompany great opportunities. The possibility of destruction is always implicit in the act of creation" (1971, p. xxiv). Social justice advocacy is not without risks the deeper one moves into confronting entrenched systems and powerful interests. Changing internal structures of political and social systems is quite distinct from advocating those systems for funding or policy changes already within their prerogative to supply (Jenkins, 2002). Therefore, the authors strongly support the freedom of counselors to choose the levels of involvement and the activities engaged in as advocates and/or political activists that are congruent with their professional and political skills, cultures, developmental levels and personal attributes. Not everyone is cut out to function well in the intensity of the political arena or has the emotional temperament to do so (Smith et al., 2009).

Finally, social justice advocacy competencies included in the code of ethics by the ACA provide a strong foundation for advocacy work but may not represent a thorough understanding of the political environment in terms of the political strategic implications of various interventions and the influence of power on policy outcomes. As a result, the value in understanding the political context of power in social justice advocacy work and experience in the public arena is a continued necessity for the social justice advocacy movement to go forward within the counseling profession.

\section{Future Implications}

Future implications for the practice of social justice advocacy center on personal constraints of time and monetary compensation, training and evidenced based interventions for best practice outcomes. In spite of the push for social justice advocacy across other fields of therapeutic endeavor including social work, community psychology and marriage and family therapy, "the literature that goes beyond practice wisdom is still less than extensive" (McNutt, 2012, p. 402). More evidenced-based studies are required on the effectiveness of advocacy interventions for best practices guidelines and to justify funding training programs. In a ten-year review of counseling research informing practice only $6 \%$ of the articles dealt with effectiveness of 
interventions overall (Ray, Hull, Thacker, Pace, Swan, Carlson, \& Sullivan, 2011). Scholars have recently begun to conduct studies of advocacy interventions by examining practices in the social political arena in tightly structured experiments. However, the onus is on counselors to build a comprehensive body of knowledge by documenting the effectiveness of social justice counseling interventions in spite of the frustrating and circuitous nature of advocacy work (Lopez-Baez \& Paylo, 2009; McNutt, 2011).

Future training will be "...required to expand service delivery skills to include preventive interventions, client advocacy and social action" (Speight \& Vera, 2004, p 116). Recently chapters on social justice in textbooks of core counseling courses are increasing along with the awareness of the impact of external environments on individual clients. This awareness is then part of a student's framework when working in the community during the practicum and internship components of their coursework. However, further training in relevant theory, skills, ethics and praxis will be necessary to produce competent social justice advocates. With cutbacks in university funding in general and degree program courses in particular, a more practical approach to social justice training may be to emphasize and work towards establishing a post graduate program in social justice counseling leading to national certification in advocacy work. In addition, most counselor educators in continuing education do not have formal training or experience as social justice advocates to teach courses in advocacy (Toporek, et al., 2009). Therefore, continued efforts towards developing core policy/legislative advocacy skills by providing training for educators would assist in the development of counseling professionals as effective social justice advocates.

Due to the complex strategic and consuming nature of advocacy work, simply adding on a social justice component within other course offerings or continuing education will not be enough to insure competent advocates in the field. Political strategy and even strategic thinking can only be taught up to a certain point, and then indirectly through examples. Strategic thinking must be acquired working in the political environment itself through mentoring and internships such as the opportunities for paid professional internships on Capitol Hill provided by the American Psychology Association. In that way advocates can move beyond merely analyzing organizations, rules and procedures to exercising strategic expertise with sound judgment and intuitive hunches based on experience, which characterize effective political operatives.

Lack of monetary compensation for time-consuming advocacy activities and time constraints are also always an issue even at the micro level. Administrators and policy makers in human services departments, at the state and national levels, do not generally support social justice advocacy services so advocacy work is more often than not pro bono (Helms, 2003). Human service delivery systems may need to be structurally changed to institute policies that recognize and act on the social justice imperative before a large scale shift of counselors into social justice advocacy interventions (at least on the macro level) could take place.

This being said, the future of social justice advocacy in overcoming barriers to practice may lie in the use of technology such as, emails, websites, blogs, wikis, smart phones, live streaming video content and social media networking. These tools offer the potential for counselors to greatly expand access to constituencies and effect social change in real time. The efficient use of technology also has the potential to greatly reduce or eliminate some of the aforementioned challenges such as lack of broad and immediate access to targeted constituencies, as well as, 
the consumption of large amounts of time and money necessary to engage resistant political systems and institutions.

In addition, the use of technology to evaluate some intervention outcomes such as online political communication and organization (e-petition signatures, online letter-writing campaigns, Facebook counts, tweets, and counting open rates of emails) becomes easier to measure (McCafferty, 2011; McNutt, 2012). Technology, therefore, offers social justice advocates a huge potential advantage to connect and mobilize the "forces of justice" to interact, share and pursue goals in support of social change with little time and monetary investment. Although the internet offers established social media platforms for increasing the capability for calls to action and assisting in organizational logistics, activism will always be about people eventually showing up to put a face on the struggle for justice against entrenched powerful interests (McCafferty, 2011).

\section{Conclusion}

Social justice advocacy will continue to play an important role in the evolution of the counseling profession. The debate on the social justice agenda and its implementation within the profession will also continue. More research to determine best practices and advocacy training is needed to inform the debate around the movement going forward. Furthermore, the goal of the social justice movement to connect client distress with social/political factors within the larger public arena will benefit from a thorough knowledge of the power dynamics involved in both policy/legislative advocacy and political activism. This understanding will assist counselors to implement necessary political strategies and overcome significant challenges associated with the role of social change agent. Counselors stand to gain from a much needed and expanded perspective on political power as the profession decides how best to move towards the development of a fifth force to promote the cause of social justice in the larger public arena for our clients and the communities in which they live.

Contact information:

Marian A. Lee

University of South Florida

Email: malee7612@hotmail.com

\section{References}

Aldarondo, E. (2007). Rekindling the reformist spirit in the mental health profession. In E. Aldarondo (Ed.), Advancing social justice through clinical practice (pp. 3-17). Mahwah, $\mathrm{NJ}$ : Lawrence Erlbaum Associates.

Alinsky, S. D. (1971). Rules for Radicals: A Pragmatic Primer for Realistic Radicals. New York, NY: Random House, Inc. 
Allen, J. (2003). Lost Geographies of Power. Oxford, UK: Blackwell Publishing.

Almeida, R., Dolan-Del Vecchio, K., \& Parker, L. (2008). Transformative family therapy: Just families in a just society. Boston: Pearson Education.

Angelique, H. L. (2008). On power, psychopolitical validity, and play [Commentary]. Journal of Community Psychology. 36(2), 246-253.

Arredondo, P., \& Perez, P. (2003). Expanding multicultural competence through social justice leadership. The Counseling Psychologist, 31(3), 282-289.

Arredondo, P., Tovar-Blank, Z. G., \& Parham, T. A. (2008). Challenges and promises of becoming a culturally competent counselor in a sociopolitical era of change and empowerment. Journal of Counseling \& Development, 86(3), 261-268.

Birnbaum, R. (2000). Policy scholars are from Venus; policy makers are from Mars. The Review of Higher Education, 12, 119-132.

Chang, C. Y., Crethar, H. C., \& Ratts, M. J. (2010). Social justice: A national imperative for counselor education and supervision. Counselor Education \& Supervision, 50(2), 82-87.

Crethar, H. C., Rivera, E., \& Nash, S. (2008). In search of common threads: Linking multicultural, feminist, and social justice counseling paradigms. Journal of Counseling \& Development, 86(3), 269-278.

Crethar, H.C., \& Winterowd, C.L. (2012). Values and social justice in counseling. Counseling and Values, 57, 3-9.

Culley, M. R., \& Angelique, H. (2011). Participation, power, and the role of community psychology in environmental disputes: A tale of two nuclear cities. American Journal of Community Counseling, 47, 410-426.

DeLeon, P. H., Frohboese, R., \& Meyers, J. C. (1984). Psychologist on Capitol Hill: A unique use of the skills of the scientist/practitioner. Professional Psychology: Research and Practice, 15(5), 697-705.

Doherty, W.J., \& Carroll, J. S. (2002). The citizen therapist and family-centered community building: Introduction to a new section of the journal. Family Process, 41(4), 561-568.

Doherty, W. J. (2008). Beyond the consulting room: Therapists as catalysts of social change. Psychotherapy Networker, 1-9.

Doherty, W. J., Mendenhall, T. J., \& Berge, J. M. (2010). The families and democracy and citizen health care project. Journal of Marital and Family Therapy, 36(4), 389-402.

Durenberger, D., \& Rotte, S. B. (1993). Beyond instrumentalism: Designing an infrastructure for reform. American Psychologist, 43(3), 277-282. 
Fryer, D. (2008). Power from the people? Critical reflection on a conceptualization of power. Journal of Community Psychology, 36(2), 238-245.

Fox, D. (2008). Confronting psychology's power. Journal of Community Psychology, 36(2), 232-237.

Goodman, L. A., Liang, B., Helms, J. E., Latta, R. E., Sparks, E., \& Weintraub, S. R. (2004). Training counseling psychologists as social justice agents: Feminist and multicultural principles in action. The Counseling Psychologist, 32(6), 793-837.

Graham, H. D. (1990). The Civil Rights Era: Origins and Development of National Policy. New York, NY: Oxford University Press.

Helms, J. (2003). A pragmatic view of social justice. The Counseling Psychologist, 31(3), 305313.

Jacobs, D.H. (1994). Environmental failure: Oppression is the only cause of psychopathology. Journal of Mind and Behavior, 15, 1-18.

Jansson, B. S. (2003). Becoming An Effective Policy Advocate: From Policy Practice to Social Justice. Pacific Grove, CA: Thomson Learning, Inc.

Jenkins, S. (2002). Organizing, advocacy, and member power: A critical reflection. WorkingUSA. 6(2), 56-89.

Kiselica, M. S., \& Robinson, M. (2001). Bringing advocacy counseling to life: The history, issues, and human dramas of social justice work in counseling. Journal of Counseling \& Development, 79, 387-397.

Kiselica, M. S. (2004). When duty calls: The implications of social justice work for policy, education and practice in the mental health professions. The Counseling Psychologist. $32(6), 838-854$.

Lee, C.C., \& Rodgers, R. A. (2009). Counselor advocacy: Affecting systemic change in the public arena. Journal of Counseling \& Development, 87(3), 284-287.

Lee, J.A., DeLeon, P. H., Wedding, D., \& Nordal, K. (1994). Psychologists' role in influencing congress: The process and the players. Professional Psychology: Research and Practice, 25(1), 9-15.

Lens, V. (2005). Advocacy and argumentation in the public arena: A guide for social workers. Social Work, 50(3), 231-238.

Lopez-Baez, S. I., \& Paylo, M. J. (2009). Social justice advocacy: Community collaboration and systems advocacy. Journal of Counseling \& Development, 87(3), 276-283. 
Lorion, R. P., \& McMillan, D. W. (2008). Does empowerment require disempowerment? Reflections on psychopolitical validity. Journal of Community Psychology, 36(2), 254260.

McCafferty, D. (2011). Activism vs. slacktivism. Communications of the ACM, 54(12), p 17-19.

McCarty, N. (2007). The policy effects of political polarization. In P. Pierson \& T. Skocpol (Eds.), The Transformation of American Politics: Activist Government and the Rise of Conservatism (pp.223-255). Princeton, NJ: Princeton University Press.

McNutt, J. (2011). Is social work advocacy worth the cost? Issues and barriers to an economic analysis of social work political practice. Research on Social Work Practice, 21(4), 397403.

Niebuhr, R. (1932). Moral Man and Immoral Society. New York, NY: Charles Scribner's Sons.

Partridge, W. L. (2008). Praxis and power. Journal of Community Psychology, 36(2), 161-172.

Phillips, D. A. (2000). Social policy and community psychology. In J. Rappaport and E. Seidman (Eds.), Handbook of Community Psychology (pp. 397-419). New York, NY: Sluwer Academic/Plunum Publishers.

Prilleltensky, I. (2008). The role of power in wellness, oppression, and liberation: The promise of psychopolitical validity. Journal of Community Psychology, 36(2), 116-138.

Prilleltensky, I., \& Fox, D. R. (2007). Psychopolitical literacy for wellness and justice. Journal of Community Psychology, 35(6), 793-805.

Ratts, M. J. (2009). Social Justice Counseling: Toward the development of a fifth force among counseling paradigms. Journal of Humanistic Counseling, Education \& Development, $48(2), 160-172$.

Ratts, M.J. (2011). Multiculturalism and social justice: Two sides of the same coin. Journal of Multicultural Counseling and Development, 39, 24-37.

Ray, D. C., Hull, D. M., Thacker, A. J., Pace, L.S., Swan, K. L., Carlson, S. E., \& Sullivan, J. M. (2011). Research in counseling: A 10-year review to inform practice. Journal of Counseling \& Development, 89(3), 349-359.

Riger, S. (1993). What's wrong with empowerment. American Journal of Community Psychology, 23, 279-292.

Ringen, S. (2008). Robert A. Dahl: Defender of democracy. In Society (pp. 283-287). Springer Science \& Business Media B.V.

Rountree, M. A., \& Pomeroy, E.C. (2010). Bridging the gaps among social justice, research, and practice [Editorial]. Social Work, 55(4), 293-295. 
Skocpol, T. (2007). Government activism and the reorganization of American civic democracy. In P. Pierson \& T. Skocpol (Eds.), The Transformation of American Politics: Activist Government and the Rise of Conservatism (pp. 39-67). Princeton, NJ: Princeton University Press.

Sharp, G. (2010). From Dictatorship to Democracy: A Conceptual Framework for Liberation (Fourth Edition). Boston, MA: The Albert Einstein Institution.

Silverstein, C. (2007). Wearing two hats: The psychologist as activist and therapist. Journal of Gay \& Lesbian Psychology, 11(3/4), 9-35.

Smith, S. D., Reynolds, C. A., \& Rovnak, A. (2009). A critical analysis of the social advocacy movement in counseling. Journal of Counseling \& Development, 87, 483-491.

Speer, P. W. (2008). Social power and forms of change: Implications for psychopolitical validity. Journal of Community Psychology, 36(2), 199-213.

Speight, S. L., \& Vera, E. M. (2004). A social justice agenda: Ready or not? The Counseling Psychologist, 32(1), 109-118.

Stivachtis, Y. A. (2008). Power in the contemporary international society: International relations meets political and social theory-a critical appraisal of U.S. foreign policy. Journal of Political and Military Sociology, 36(1), 85-101.

Taskforce on Psychology and Public Policy. (1986). Psychology in the public forum: Psychology and public policy. American Psychologist, 41(8), 914-921.

Toporek, R.L., Lewis, J.A., \& Crethar, H.C. (2009). Promoting systemic change through the ACA advocacy competencies. Journal of Counseling \& Development, 87, 260-268.

Vincent, T.A. (1990). A view from the hill: The human element in policy making on Capitol Hill. American Psychologist, 45(1), 61-64.

Winter, D. G. (2010). Why achievement motivation predicts success in business but failure in politics: The importance of personal control. Journal of Personality, 78(6), 1637-1668.

Wilkinson, R. D., \& Pickett, K. (2009). The Spirit Level: Why More Equal Societies Almost Always Do Better. London, United Kingdom: Allen Lane/Penguin Group UK.

Wolff, T. (2000). Practitioners' perspectives. In J. Rappaport, E. Seidman (Eds.), Handbook of Community Psychology (pp. 741-777). Dordrecht Netherlands: Kluwer Academic Publishers.

Zimmerman, M.A. (1995). Psychological empowerment: Issues and illustrations. American Journal of Community Psychology, 23, 581-599. 